\title{
Energy Efficient Use of Microclimatic Elements and Today's Interpretation in Mardin Traditional Housing Architecture
}

\author{
F. Demet Aykal (Corresponding author) \\ Faculty of architecture, Dicle University \\ Diyarbakir, Turkey \\ E-mail: demetaykal@gmail.com \\ Kubra Suna \\ Faculty of architecture, Dicle University \\ Diyarbakir, Turkey \\ E-mail: kbsuna@gmail.com \\ Kubra Kochan \\ Faculty of architecture, Dicle University \\ Diyarbakir, Turkey \\ E-mail: kbrkchnn@gmail.com
}

\begin{abstract}
Traditional microclimatic elements are characteristic elements created by the influence of physical and socio-cultural environment in societies that share a common culture. Designing these elements in accordance with the climate zone plays an important role in energy efficient use. In this study, microclimatic elements used in Mardin traditional houses their contributions to energy efficient usage were investigated. For this purpose, the role of microclimatic elements used in design of buildings and spaces in energy efficient design has been questioned

In this study, a questionnaire of 10 questions was applied to 60 users. The questionnaire was evaluated under two sub-headings as socio-demographic characteristics and the effect of microclimatic elements on users. The effects of microclimatic elements (courtyard, iwan, portico, window and solar control element) on the users were interpreted graphically and given in tabular form. It has been determined that these elements used in traditional houses of Mardin provide energy saving and provide comfortable spaces to the users.

The suggestions were made by comparing the past and present uses of these items. Considering the data obtained from the findings, it was seen that new interpretations can be brought to traditional microclimatic elements in today's conditions.
\end{abstract}

Key Words: Traditional Mardin houses, Microclimatic elements, Energy

DOI: $10.7176 / \mathrm{JSTR} / 5-12-10$

\section{Mardin Geleneksel Konut Mimarisinde Mikroklimatik Öğelerin Enerji Etkin Kullanımı Ve Günümüz Yorumu}

Özet

Geleneksel mikroklimatik öğeler, ortak bir kültürü paylaşan toplumların fiziksel ve sosyo-kültürel çevrenin etkisiyle oluşturduğu karakteristik öğelerdir. Bu öğelerin bulunduğu iklim bölgesine uygun tasarlanması, enerji etkin kullanımda önemli bir rol oynamaktadır. Çalışmada Mardin geleneksel konutlarında kullanılan mikroklimatik öğelerin neler olduğu ve enerji etkin kullanıma katkıları araştırılmışıtır. Bu amaçla tasarımda kullanılan mikroklimatik öğeler olan bina ve mekânların enerji etkin tasarımda rolü sorgulanmıştır.

Çalışmada 60 kullanıcıya 10 soruluk anket uygulanmıştır. Anket sosyo-demografik özellikler ve mikroklimatik öğelerin kullanıcılar üzerindeki etkisi olmak üzere iki alt başlıkta değerlendirilmiştir. Mikroklimatik öğelerin (avlu, eyvan, revak, pencere ve güneş kontrol elemanı) kullanıcılar üzerinde 
etkileri grafiklerle yorumlanmış ve tablo halinde verilmiştir. Mardin geleneksel konutlarında kullanılan bu öğelerin enerji tasarrufu sağlayıp kullanıcılara konforlu alanlar sunduğu tespit edilmiştir.

Oluşturulan öneriler bu öğelerin geçmiş kullanımları ile günümüzdeki kullanımları karşılaştırılarak gerçekleştirilmiştir. Bulgulardan elde edilen veriler göz önüne alınarak, geleneksel mikroklimatik öğelere günümüz koşullarında yeni yorumlamalar getirilebileceği görülmüştür.

Anahtar Kelimeler: Geleneksel Mardin konutları, Mikroklimatik öğeler, Enerji

\section{GİRIŞ}

Enerji üretimi için gerekli olan kaynakların sınırlı olması, üretimde çevreye verilen zarar ve üretim maliyetinin yüksek oluşu enerji tasarrufunu zorunlu hale getirmektedir. Enerji tasarrufu son zamanlarda enerji tüketimine ilişkin önlemleri içerirken, önemli bir bölümü de yenilenebilir enerji kaynaklarından yararlanma yollarına yoğunlaşmaktadır.

Günümüzde konut tasarımlarında enerji tüketimi her geçen yıl artmaktadır. Konutlarda kullanılan enerjinin büyük bir kısmı kullanıcıların iklimsel konforunu sağlamak için mekânların ısıtılmasında veya soğutulmasında harcanmaktadır. Tasarımda iklim etkisi iyi analiz edildiği sürece binanın enerji etkinliği doğal olarak sağlanabilmekte ve kullanıcıya daha konforlu ortamlar sunulabilmektedir (Koca, 2006).

Günümüzde konut tasarımlarında bölge iklimi göz ardı edilmektedir. Dolayısıyla enerjinin doğru değerlendirilememesi enerji tüketimine neden olmaktadır. Artan enerji tüketimi çevreye ve insanlara zarar vermektedir.

Konutlarda geleneksel mikroklimatik öğelerin kullanılması enerji tüketimini azaltmaktadır. Böylece kullanıcılar için daha ekonomik kullanım şekli olmaktadır. Çalışma temel olarak bu hipotez üzerinden yürütülmüştür. Bunun en güzel örnekleri tarihi konut dokularında görülmektedir. Bu dokulardan biri de Mardin geleneksel konut dokusudur.

Çalışmada Mardin geleneksel konutlarında kullanılan mikroklimatik öğelerin enerji etkinliği ele alınmıştır. Konut tasarım aşamasında bu öğelerinin kullanımının önemi belirtilerek yeni yapılacak konut tasarımlarında mimara bir kaynak sunulması hedeflenmiştir. Dolayısıyla geleneksel konut mimarisinde kullanılan avlu, eyvan, revak, pencere ve güneş kontrol elemanlarının mikroklimatik öğe olarak yönlenmesi, konumlanması ile kullanımı araştırmanın alt hipotezini oluşturmuştur.

Ülkemizde sıcak kuru iklime sahip Mardin'de, geleneksel konutlarda kullanılan mikroklimatik öğelerin enerji etkin kullanımları bina ölçeğinde ve mekân ölçeğinde ayrı ayrı ele alınmıştır. Bina ölçeğinde avlu, eyvan, revak gibi öğeler; mekân ölçeğinde ise pencereler ve güneş kontrol elemanları incelenmiştir.

Araştırmada veri toplama aracı olarak anket tekniği kullanılmıştır. Anket çalışması iki bölümden oluşmuş ve bire bir görüşme ile uygulanmıştır. Çalışma Ağustos ayında 20 Mardin geleneksel evi rastsal olarak seçilip, seçilen her evden 3 kişiye anket uygulanarak yapılmıştır. Anketle Mardin geleneksel konutlarında yaşayan halka, sosyo-demografik özelliklerine yönelik sorular ve mikroklimatik öğelerin enerji etkin kullanımına yönelik farkındalıklarını belirlemek üzere likert yöntemiyle kurgulanan sorular yöneltilmiştir. Böylelikle mimar gözüyle belirlenen mikroklimatik öğelerin fonksiyonelliğinin kullanıcı tarafından da onaylanıp onaylanmadığı belirlenmiştir. Anketler SPSS programı ile değerlendirilmiştir. Verilerin değerlendirilmesinde kullanılan yüzde dağılımlara ilişkin istatistiksel veriler tablo ve grafikler şeklinde ifade edilmiştir.

Son olarak anket sonuçlarına göre Mardin geleneksel evlerinde kullanılan mikroklimatik öğelerin günümüz koşullarında kullanılmasına yönelik öneriler sunulmuştur.

\section{GELENEKSEL MARDIN MIMARISINDE MIKROKLIMATIK ÖĞELER}

Mardin şehir dokusunun biçimlenmesinde iklimsel veriler etkili olmuştur. Güneydeki çöl ikliminin etkisi ve kuzeydeki yüksek dağların serin havanın bölgeye girmesini engellemesi yaz aylarının çok sıcak geçmesine sebep olmaktadır. Bu durum Mardin geleneksel konutlarının iklim verileri dikkate alınarak tasarlanmasını zorunlu kılmıştır.

Mikroklimanın tanımı yapılırken konuya çeşitli açılardan yaklaşılabilmektedir. Meteorolojik açıdan bakıldığında mikroklima, belirli iklim elemanları ve onlarla bağıntılı yer şekli birimlerinin oluşturduğu bir fiziksel ortamdır. Bunlar göz önüne alındığında mikroklima genel olarak, insan ve çevre aktivitelerini, başka bir söylemle karasal hayatı etkileyen, doğal ekosistemlerin korunmasıyla yakından ilgilenen bir konudur (Sür, 1980).

Mardin geleneksel mimarisinde mikroklimatik öğeler iki ayrı parametrede incelenmiştir. Bunlar; bina ölçeği ve mekân ölçeğindedir (Tablo 1). 
Tablo 1: Mikroklimatik Öğelere Ait Parametreler

\begin{tabular}{|c|c|}
\hline Bina ölçeği & Mekân ölçeği \\
\hline - $\quad$ Avlu & - $\quad$ Pencereler \\
\hline - $\quad$ Eyvan & - $\quad$ Güneş kontrol elemanları \\
\hline - $\quad$ Revak & \\
\hline
\end{tabular}

\subsection{Bina Ölçeği}

Mikroklimatik öğeler, bütüncül yaklaşım anlayışıyla bina tasarım aşamasında düşünülerek enerji tasarrufu sağlamak amacıyla kullanılabilmektedir. Mardin geleneksel evlerinde bina ölçeğinde mikroklimatik öğe olarak; avlu, eyvan ve revak ele alınmıştır.

\subsubsection{Avlu}

Avlu etrafı yapıya ait duvar ya da mekanlarla çevrelenmiş üstü açık mimari birimlerdir. Tarihin eski zamanlarından bu yana farklı iklim bölgelerinde avlu kullanımlarına rastlanmaktadır. Avluların boyutları ve şekilleri bulunduğu yerin iklim özelliklerine göre değişmektedir. Düşük hava sıcaklığına sahip bölgelerde güneşi mekanın içine almak için geniş, yüksek hava sıcaklığına sahip bölgelerde ise güneşten korunmak için küçük tasarlanmıştır. Avluların iklimsel karakteristikleri 3 kategoride incelenebilmektedir (Şekil 1).

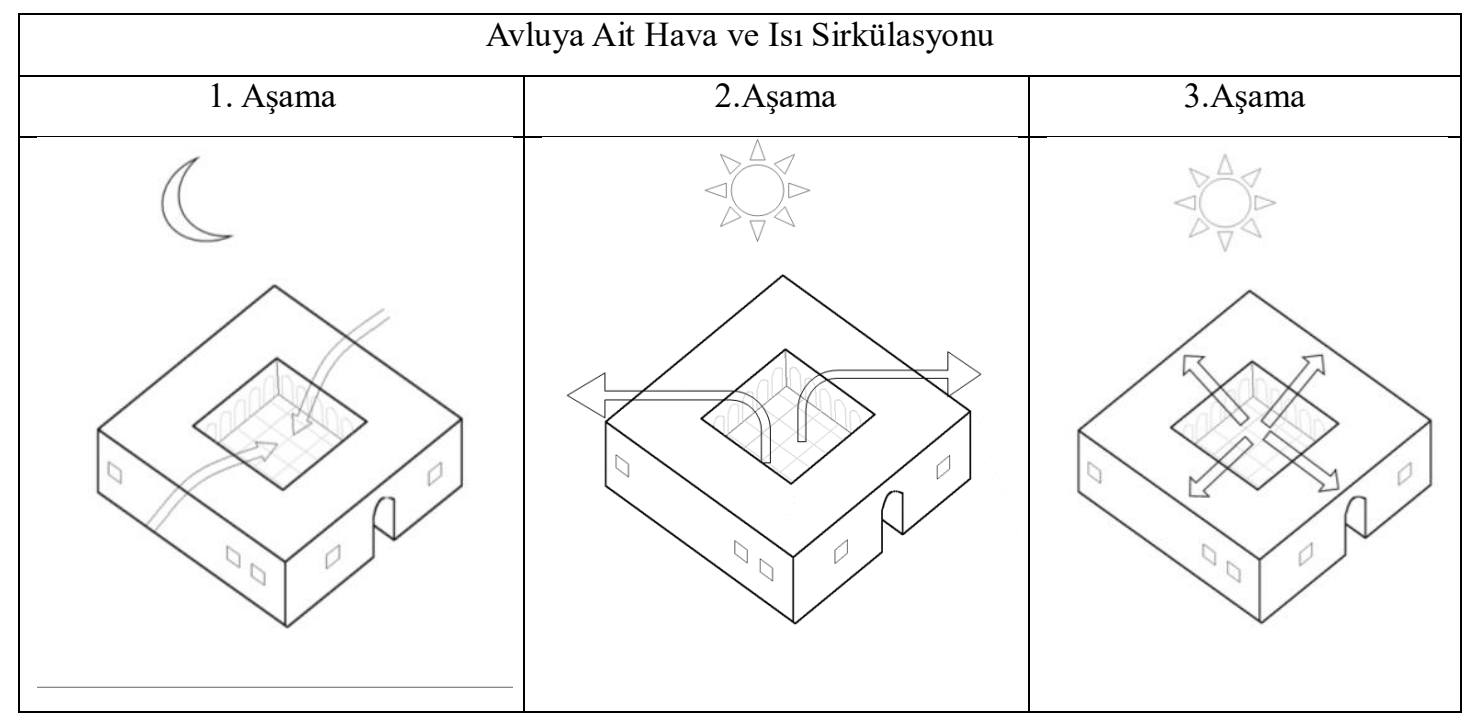

Şekil 1 : Avlularda Gerçekleşen Hava ve Isı Sirkülasyonun Diagramatik Açıklaması (Koca, 2006)

İlk olarak; gece soğuk hava avluya inerek etrafındaki odaları serinletmektedir. Serinleyen oda öğleden sonra geç vakitlere kadar bu şekilde kalmaktadır. Ayrıca avlu gökyüzüne doğru ters ışıma ile 1sı vermektedir.

İkinci olarak; gün ortasında güneş ışınları doğrudan avlu zeminine vurmaktadır. Soğuk havanın bir bölümü yükselmeye başlarken, bir kısmı etrafındaki odaların içine sızmaktadır. Bu durum daha konforlu bir ortam için ısı taşınımı olayını gerçekleştirmektedir. Dış hava en yükssek sıcaklığına ulaştığında, avlu bu süre içerisinde baca görevi görmektedir. Sarı kalkerden yapılmış kalın duvarlar dış hava sıcaklığının hemen içeri sızmasına izin vermemektedir.

Son olarak; avlu zemini ve yapının iç mekânları ısınmaya başlamakta ve öğleden sonra ilerleyen saatlerde taşınım olayları oluşmaktadır. Odalar içinde hapsedilen soğuk havanın çoğu güneş batımıyla dışarıya doğru hareket etmektedir. Akşamüstü geç vakitlerde sokaklar, avlu ve yapı, bitişik yapıların gölgeleri ile güneş ışınlarından korunmaktadır. Güneş battığında hızla hava sıcaklığı düşmekte ve avlu gökyüzüne doğru hızla ışıma yapmaktadır. Serin hava döngüyü tamamlayarak avluya doğru yönelmektedir (Koca, 2006). 
Sıcak kuru iklim bölgesindeki avlulu konutlarda ideal hava dolaşımı dışarıya çok az olan açıklıkların tamamen avluya yönlendirilmesi ile sağlanmıştır. Özellikle Mardin yöresinde avlular tamamen iç-orta avlulu plan şemasına dönüşmüştür. Böylece oluşturulan mikroklimatik ortam doğrudan iç ortama kanalize edilebilmektedir. Avluda bulunan bitkiler ve su öğeleri rüzgarın havada oluşan nemi alıp götürmesini engellemektedir. Ayrıca mikroklima düzenleyicisi görevi yüklenen avlular, dışa kapalı bir şekilde birbirine yanaşarak hatta bitişerek bir hücre yapı oluşturmuşlardır. Bu hücre yapının ortaya çıkardığı kent dokuları içi boşluklu tek bir yapı görünümündedir. Bu tür bir yapılaşmada ısı kaybı ve kazanc1, doğal olarak en aza indirgenmiştir (Şimşek, 2013) (Resim 1).
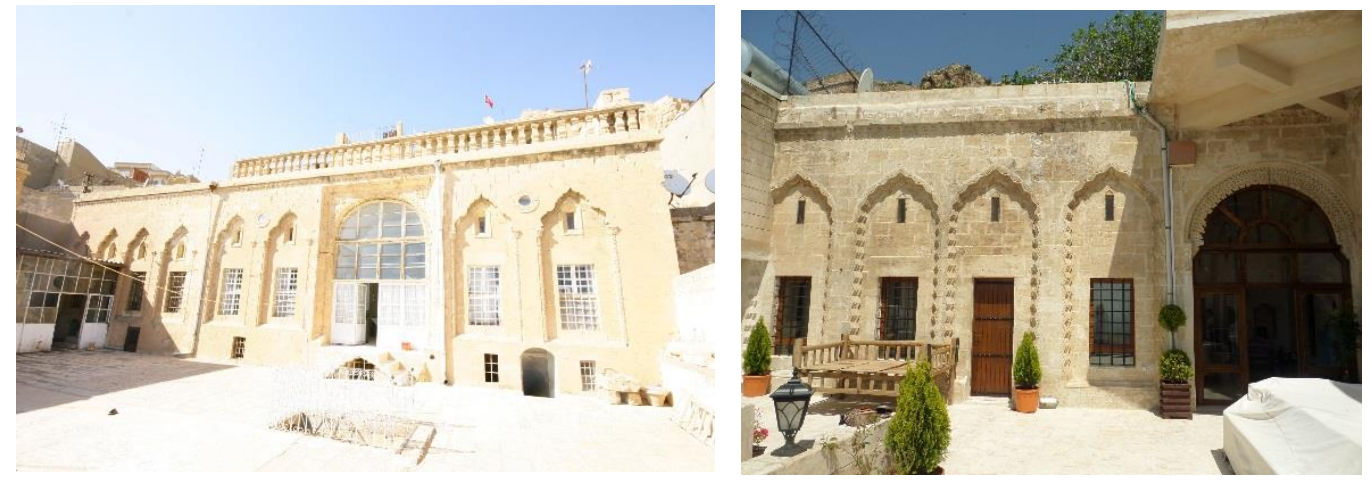

Resim 1: Mardin geleneksel mimarisinde avlu örneği (Mimar Cudi Nas ve Mimar Mehmet Topalan arşivinden )

Mardin geleneksel evlerinde avlu, sıcak kuru iklim bölgeleri için konforu sağlayan en önemli çözüm önerilerinden biri durumundadır. Kütle boyutuna bağlı olarak uygun oranlarda kurgulanan avlunun güneş kontrolünü gerektiği gibi sağladığını, hatta su yüzeyi ve bitkilerle de nem oranının istenen seviyeye çıkardığı gözlemlenmiştir. Bu yöredeki evler tasarlanırken güneye yönlendirilerek kademeli olarak kuzeye doğru yükseltilmiştir. Yapıda, giriş katlarındaki avlu duvarları yüksek tutularak gün boyunca gölgeli alanların oluşması sağlanmıştır (Manioğlu, 2008) (Salur, 2016) (Resim 2).
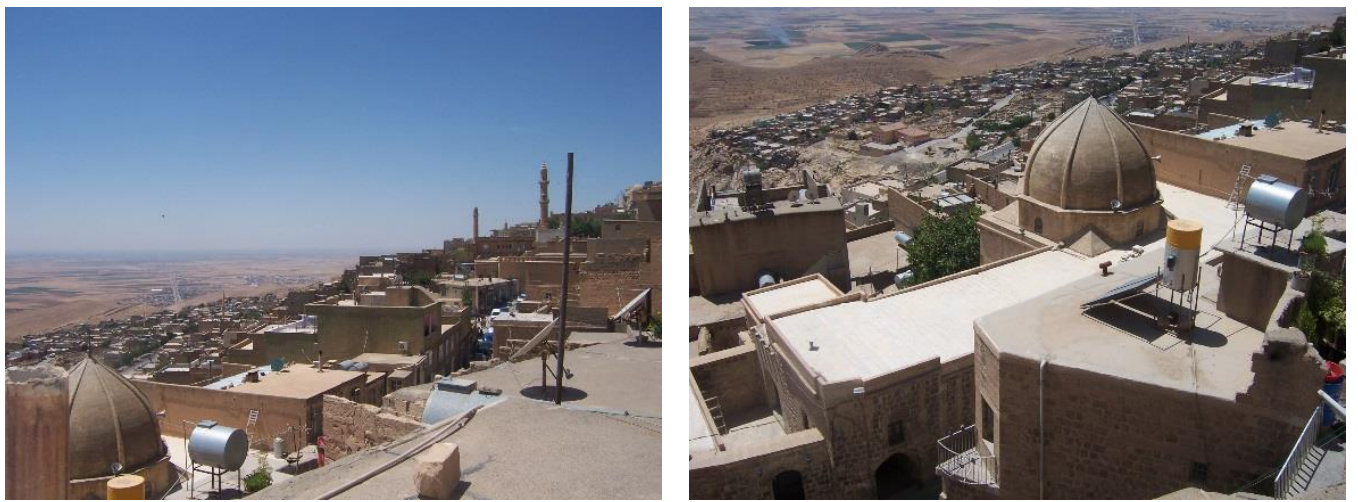

Resim 2: Mardin geleneksel mimarisinde evlerin kademeli yerleşimi (Mimar Cudi Nas ve Mimar Mehmet Topalan arşivinden)

\subsubsection{Eyvan}

Eyvan, Mardin geleneksel evinde yaygın olarak kullanılmakta olup birden çok işleve sahiptir. Üç tarafı ve üstü kapalı önü ise açık olan eyvan, mahrem mekânlar olan yaşama birimleri arasında, bir yarı mahrem alan olarak odalara dağılım sağlamaktadır. Yaz mevsimi için gölgeli serin bir dinlenme alanıdır. Bazı eyvanların içerisinde su öğesi bulunmaktadır (Özbek, 2010)

Eyvanın, genellikle kare ve dikdörtgen yaşama birimleri ile birlikteliği söz konusudur. Boyutları, aralarında yer aldığı yaşama birimlerine bağlı olarak değişiklik göstermektedir. Özellikle dikdörtgen yaşama biriminin bir, iki, üç modül olabilen uzun kenarı zaman zaman eyvan derinliğini yönlendirmiştir (Alioğlu, 2000) (Resim 3). 

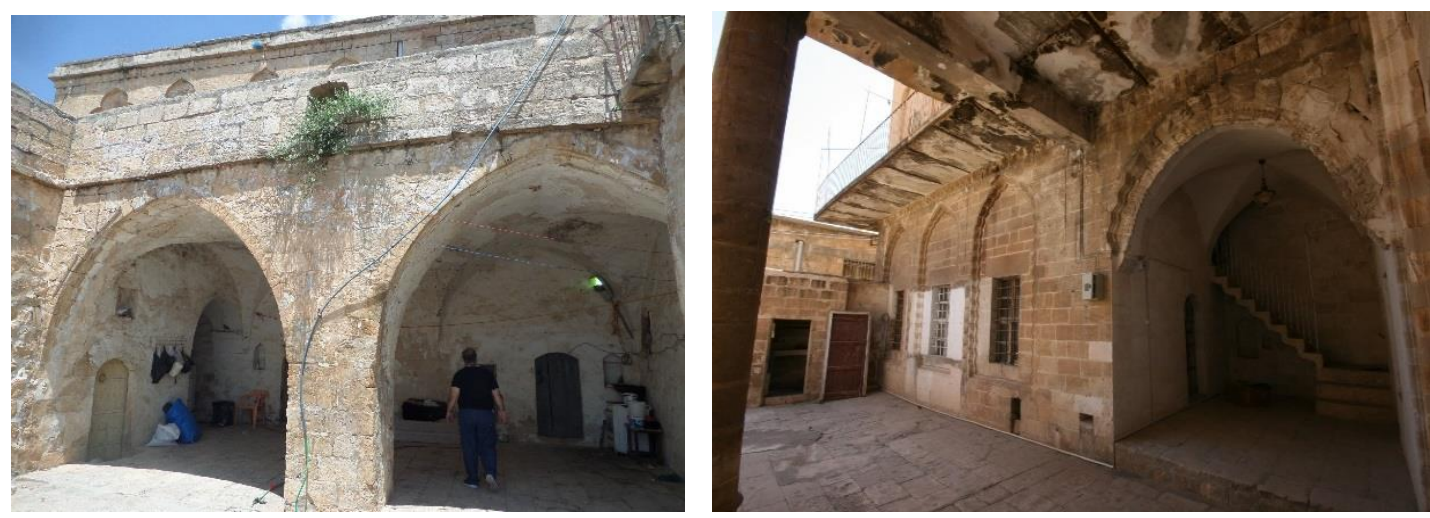

Resim 3: Mardin geleneksel mimarisinde eyvan örneği (Mimar Cudi Nas ve Mimar Mehmet Topalan arşivinden)

Eyvan Mardin geleneksel evinde; su öğesi ile birlikte, iki kapalı mekân arasında bir ara geçiş ve odalara dağılım noktası olarak kullanılmıştır. Eyvan, yaz mevsimi için gölgeli, serin bir dinlenme yeridir. Uzun süren yaz aylarında güneşin çeşitli açılarına karşı önlem alma zorunluluğu eyvanın yönlendirilmesini gerektirmiştir. Eyvan, Mardin geleneksel evi planlamasında doğu, batı ve en çok da güneye bakacak şekilde konumlandırılmıştır. Özellikle güneye ve doğuya bakan eyvanlar sıcak kuru iklim bölgesinde öğleden sonra güneşine karșı serin ve gölgeli alanlar olușturmaktadır (Manioğlu, 2008) (Șekil 2).

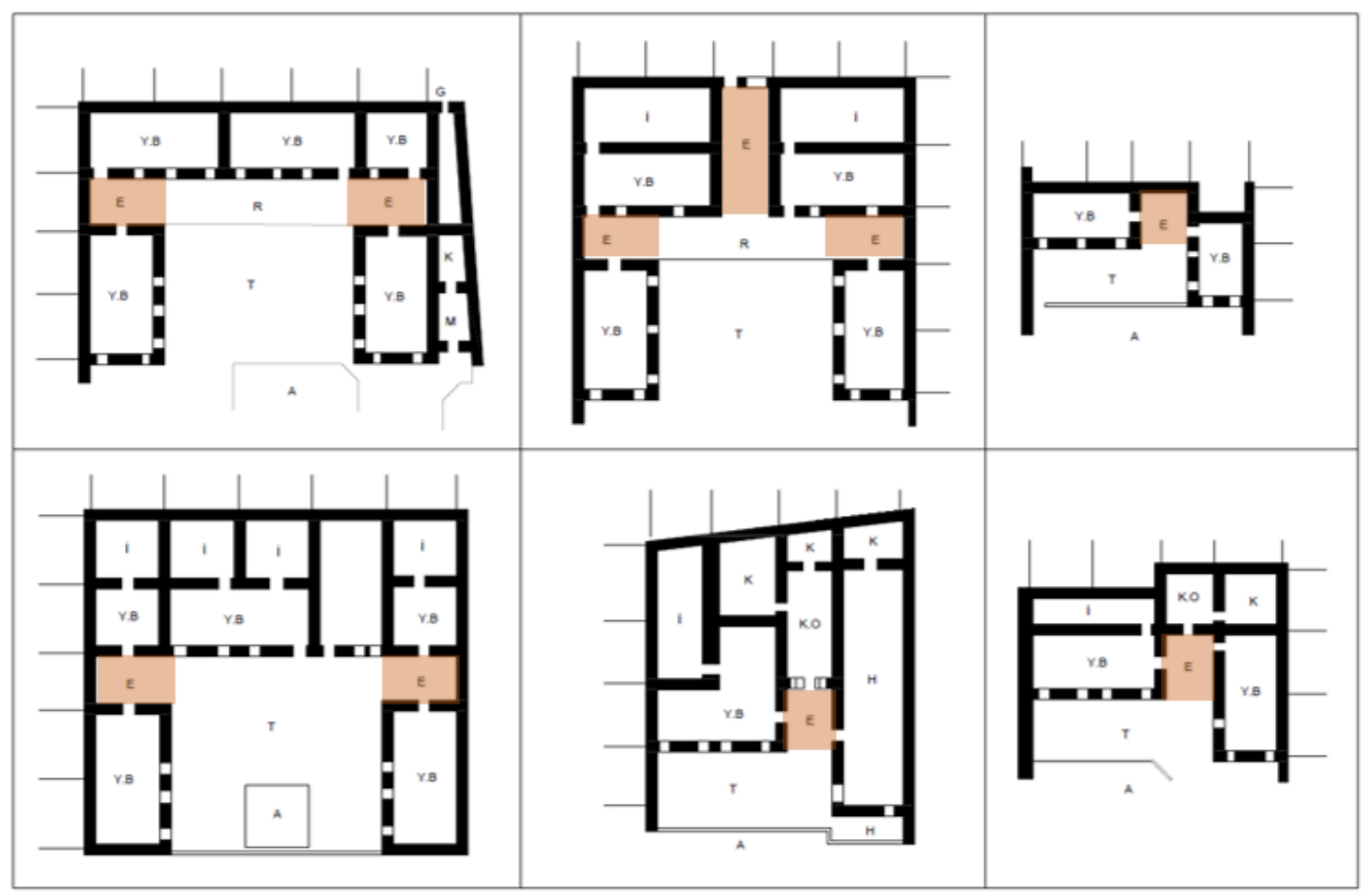

A: Avlu, E: Eyvan, H: Hela, İ: İşlik, K: Kiler, K.O: Kahve Ocağı M: Mutfak, R: Revak, T: Teras,

Y.B: Yaşama birimi

Şekil 2: Mardin geleneksel mimarisinde eyvan planı örneği (Alioğlu, 2000)

\subsubsection{Revak}

Revak, üç tarafı ve üstü kapalı olacak şekilde iki veya daha fazla birimin tekrarı şeklinde Mardin geleneksel evlerinde kullanılmıştır. Özellikle avlu çevresinde kapalı mekânlara giriş alanında yaygın olarak görülmektedir. Bunun sebebi günlük işlerin görüldüğü avluda güneşten korunarak, serin gölgeli alan oluşturmaktır. Açık mekânla kapalı mekân arasında kademeli bir geçiş sağlar. Bir ara katman olarak, yaşama mekânlarının güneşten korunmasında ve serin kalmasında etkilidir. (Özbek, 2010).

Mardin geleneksel evi tasarımında kullanılan ve yarı açık bir öğe olan revaklar, özellikle giriş katlarında 
bulunur. Girişteki avlu ile sırtını kuzeye dayamış ve güneye cephelenen yapı kitlesinin üst katlarının terasları arasında bir geçiş öğesi olarak kullanılır. Bu şekilde gün boyunca sıcak iklimin oluşturduğu konforsuzluğa karşı, güneşten korunarak serin mekânlar oluşturur (Manioğlu, 2008) (Resim 4).
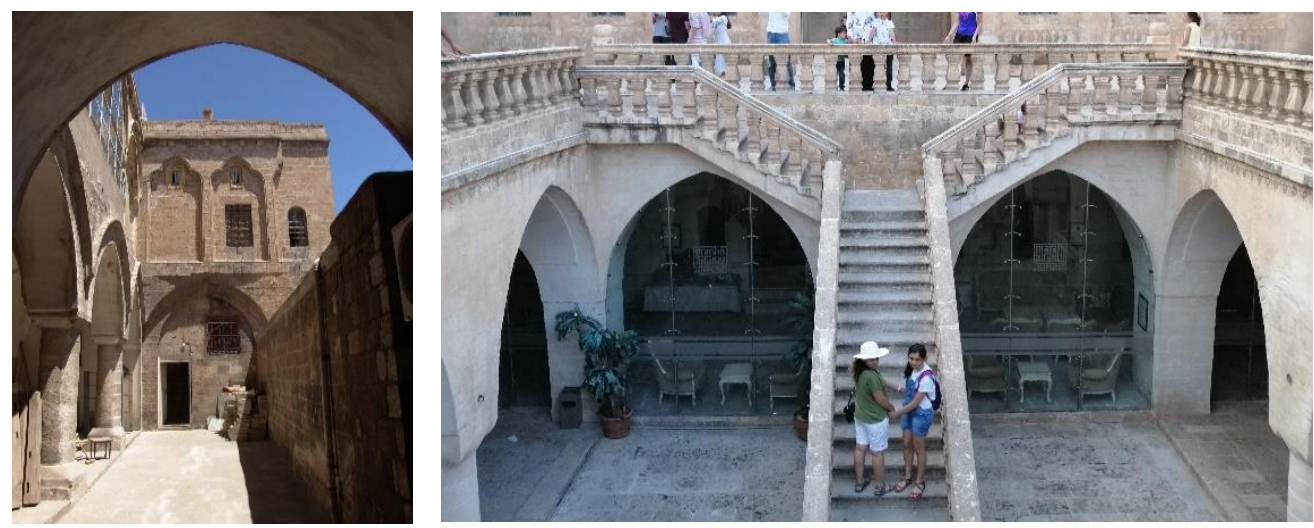

Resim 4: Geleneksel Mardin mimarisinde revak örneği (Mimar Cudi Nas, Mimar Mehmet Topalan ve Mimar Kübra Koçhan arşivinden )

Kışın geleneksel Mardin evinin ısısal performansında kullanılan revak, günün yaklaşık 10 saati iyi bir iç konfor sıcaklığına sahiptir. Bulgulara göre bu mekân yaz sıcaklarının devam ettiği Eylül ayı içinde de gün içindeki en serin mekânlardan biridir. Bu mekân, önündeki açık kemerleri ile avluya organik olarak bağlıdır. Yazın kullanılan revak ise günün 11,5 saati konforlu bir iç ortama sahiptir (Bekleyen ve ark. 2014).

\subsection{Mekân Ölçeği}

Mekân ölçeğinde, mikroklimatik öğeler enerji korunumlu tasarlanıp karakterize edilmiş elemanları içermektedir. Mardin geleneksel konutlarında mekân ölçeğinde mikroklimatik öğe olarak; pencere ve güneş kontrol elemanları ele alınmıştır.

\subsubsection{Pencereler}

Pencereler, gün ışı̆̆ından yararlanmayı, dış ortamla görsel bağlantıyı ve doğal havalandırmanın yapılmasını sağlayan öğelerdir. Pencerenin boyutu, yeri ve yönü iklimsel konfor sağlanmasında önemli rol oynamaktadır (Koca, 2006)(Resim 5).
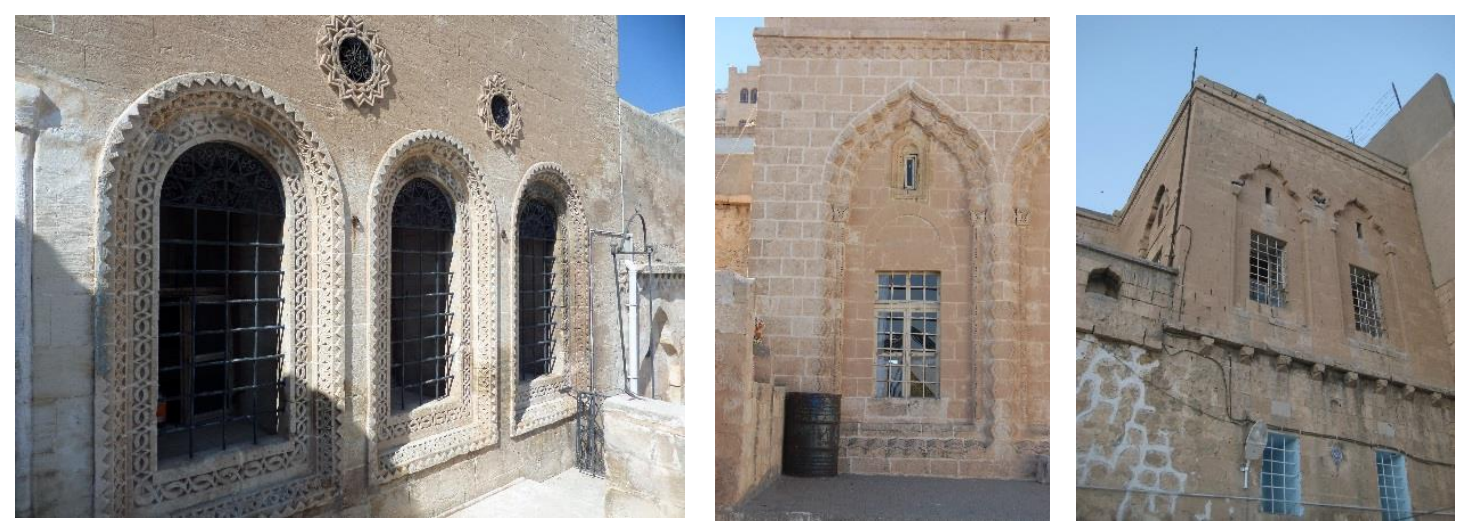

Resim 5: Geleneksel Mardin mimarisinde pencere örneği (Mimar Cudi Nas ve Mimar Mehmet Topalan arşivinden)

Mardin geleneksel evinin küçük boyuttaki ve derinliği fazla olan pencereleri, teras veya avludan doğrudan ve yansıyarak iç mekana daha az ölçüde güneş ışınlarının alınması sağlanır. 0,75-1,00 cm kalınlığında değişen duvarlar, dik gelen yaz güneşi için doğal bir güneş kırıcı işlevine sahiptir. Kış mevsiminde ise güneş ışınları eğimli bir açı ile geldiğinde iç mekana daha fazla miktarda güneş ışının alınması sağlanır (Karagülle, 2009). Mardin geleneksel evlerinde görülen pencere genişlik/yüksekliğin 
$1 / 2$ oranında olması istenilen konfor düzeyini yakalamada yardımcı olmaktadır. Pencerelerin gerektiğinden büyük olmaması, yaz mevsiminde saydam yüzeylerce fazla ısının oda içerisine alınmasını engellerken, kış mevsiminde ise ısı kaybına neden olan alanın küçültülmesiyle ısı kaybının azaltılması sağlanır (Karagülle, 2009).

Mardin geleneksel konutlarında pencereler genellikle iki sıralı olarak düzenlenmiştir. Alt sıra pencere boyutları 75-90 / 130-150 cm arasında değişkenlik göstermektedir. Alt sıra pencereler iki kanatlı ahşap kapaklarla kapatıldığında mekânın aydınlatılması için üst sıra pencerelerden gelen ışıktan faydalanılır. Tepe penceresi de olarak adlandırılan üst sıra pencerelerinin duvar dış yüzünde $20 / 40 \mathrm{~cm}$ olan ölçüleri, duvar ve iç yüzünde 55-60/ 75-80 m'ye ulaşarak büyüme gösterirler. Böylece dış duvarda 1şı̆̆ın içeriye daha çok girmesini sağlayan bir kesit oluşturulmuştur ve havalandırma kolaylaştırılmıştır (Manioğlu, 2008) (Şekil 3).

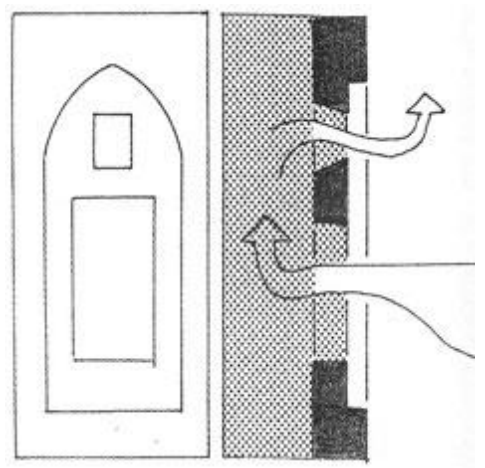

Şekil 3: Mardin geleneksel konutta pencere kesiti (Koca, 2006)

\subsubsection{Güneş Kontrol Elemanları}

Sıcak kuru iklim bölgelerindeki yerleşmelerde, avluyu çevreleyen yüksek bahçe duvarları en basit gölgeleme araçlarındandır. İç ve dış mekânlar farklı zamanlarda farklı gölgeleme uygulamalarına sahiptir. Avlu, çevresindeki mekânlara günışı̆̆ı ve gün boyu yaygın güneş 1şınımı sağlar. Sicaklık dışarıda bulunmak için uygun sıcaklığa düştüğünde ağaçlar gölge sağlar ve çalılarda rüzgarı yönlendirir (Koca, 2006).

Geleneksel yerleşmelerde bina kabuğunun gölgelenmesinde saçak, $\operatorname{arkad}^{1}$ ve mahremiyet amaçlı kullanıma da sahip olan ızgaralar ile gölge sağlanmıştır. Çünkü ısı kayıp ve kazançlarına dair enerji tüketimine neden olan pencerelerde güneş kontrolünün sağlanması önemlidir.
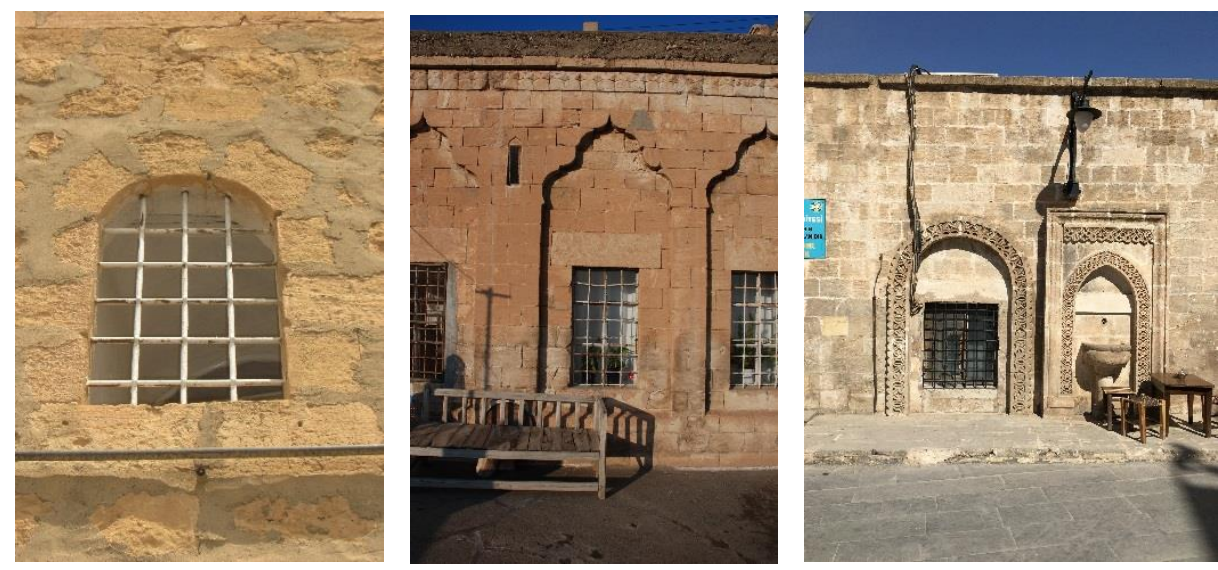

Resim 6: Mardin geleneksel konutta pencere ıggara detayı (Mimar Cudi Nas ve D. Türkan Kejanlı arşivinden)

${ }^{1}$ Arkad: Ön tarafikemerli ve açık, arka tarafi duvarlı ve üstü örtülü olan yarıaçık mekandır.

93 | $\mathrm{P}$ a g e

www.iiste.org 
$\mathrm{Bu}$ nedenle pencerelerde uygulanabilecek güneş kontrolü stratejileri (Koca, 2006) (Resim 6).

a) Pencerenin her iki yanına uzanan yatay saçaklar

b) Düşey uzun ince parçalardan oluşmuş elemanlar

c) Yatay ve düşeylerden oluşmuş ızgara şeklindeki gölgeleme elemanları şeklindedir (Koca, 2006).

\section{BULGULAR}

Araştırmada Mardin geleneksel konutlarında mikroklimatik öğelerin enerji performans değerlerinin kullanıcılar üzerindeki etkisi belirlenmiştir. Geleneksel mardin konutunda halihazırda yaşayan 60 kişiyle anket çalışması yapılmıştır. Yapılan anket sosyo-demografik özellikler ve mikroklimatik öğelerin kullanıcılar üzerindeki etkisi olmak üzere iki alt başlıkta değerlendirilmiştir.

\subsection{Sosyo-Demografik Özellikler}

Bir yapının doğru bir şekilde değerlendirilmesinde sosyal durum oldukça önemlidir. Kullanıcının yaşı, eğitimi, işi hatta bazen gelir durumu yapı değerlendirilmesinde önemli parametreler olmaktadır. $\mathrm{Bu}$ amaçla yapılan anket özellikle evleri uzun süreler kullanan ve olması gereken farkındalığ kavramış olduğu düşünülen kullanıcılara uygulanmıştır.

Kullanıcılara yaşları, cinsiyet, öğrenim durumu, meslek ve konutu kullanım yılı sorulmuştur. Sonuçlar tablo 2 de verilmiştir (Tablo 2).

Tablo 2: Konut kullanıcılarının sosyo-demografik özellikleri

\begin{tabular}{|c|c|c|c|}
\hline Kullanıcı profili & Özellikler & $\mathrm{N}$ & $\%$ \\
\hline \multirow[b]{2}{*}{ Cinsiyet } & Kadın & 42 & $\% 70$ \\
\hline & Erkek & 18 & $\% 30$ \\
\hline \multirow{4}{*}{ Yaş } & $15-25$ & 0 & $\% 0$ \\
\hline & $25-35$ & 24 & $\% 40$ \\
\hline & $35-45$ & 12 & $\% 20$ \\
\hline & 45 üstü & 24 & $\% 40$ \\
\hline \multirow{5}{*}{ Öğrenim Durumu } & Eğitim almamış & 15 & $\% 25$ \\
\hline & İlkokul & 15 & $\% 25$ \\
\hline & Ortaokul & 9 & $\% 15$ \\
\hline & Lise & 9 & $\% 15$ \\
\hline & Lisans & 12 & $\% 20$ \\
\hline \multirow{6}{*}{ Meslek } & Ticaret & 3 & $\% 5$ \\
\hline & Özel Sektör & 6 & $\% 10$ \\
\hline & Kamu Personeli & 6 & $\% 10$ \\
\hline & Öğrenci & 3 & $\% 5$ \\
\hline & Serbest & 12 & $\% 20$ \\
\hline & Ev Hanımı & 30 & $\% 50$ \\
\hline \multirow{4}{*}{ Konut Kullanım Y1lı } & $1-5$ Yil & 9 & $\% 15$ \\
\hline & $5-10 \mathrm{Yl}$ & 6 & $\% 10$ \\
\hline & 10-15 Y1l & 6 & $\% 10$ \\
\hline & 15 Yildan Fazla & 39 & $\% 65$ \\
\hline
\end{tabular}


Tabloya göre ankete katılan;

- Kullanıcıların \%70’i kadındır. Çünkü kadınlar konutları gün içerisinde erkeklere göre daha siklıkla kullanmaktadırlar.

- Kullanıciların \% 50’si ev hanımıdır.

- Geleneksel konutlarda yaşayanların \% 40’1 45 yaş üstü ve \% 20’si 35-45 yaş arasındadır. Bundan yola çıkarak yeni neslin geleneksel konutları tercih etmediklerini söylenebilmektedir.

- Kullanıcıların \%25'i eğitim almamış \%25'i de ilkokul mezunudur. Bundan yola çıkarak anket yapılan yerin eğitim seviyesinin düşük olduğu görülmektedir.

- Kullanıcıların \% 65'i 15 yıldan fazla bu konutlarda yaşamaktadır.

\subsection{Mikroklimatik Öğelerin Kullanıcılar Üzerinde Etkisi}

Mardin kentsel sit alanında geleneksel mikroklimatik öğelerin kullanıcılar üzerinde etkisi ile ilgili sonuçlar grafiklerle belirtilmektedir. Mikroklimatik öğeler olan avlu, eyvan, revak, pencere, güneş kontrol elemanı ve havalandırma bacasının kullanıcılar üzerindeki etkileri grafiklerle yorumlanmış ve tablo halinde verilmiştir (Tablo 3).

Tablo 3: Mikroklimatik Öğelerin Değerlendirilmesi

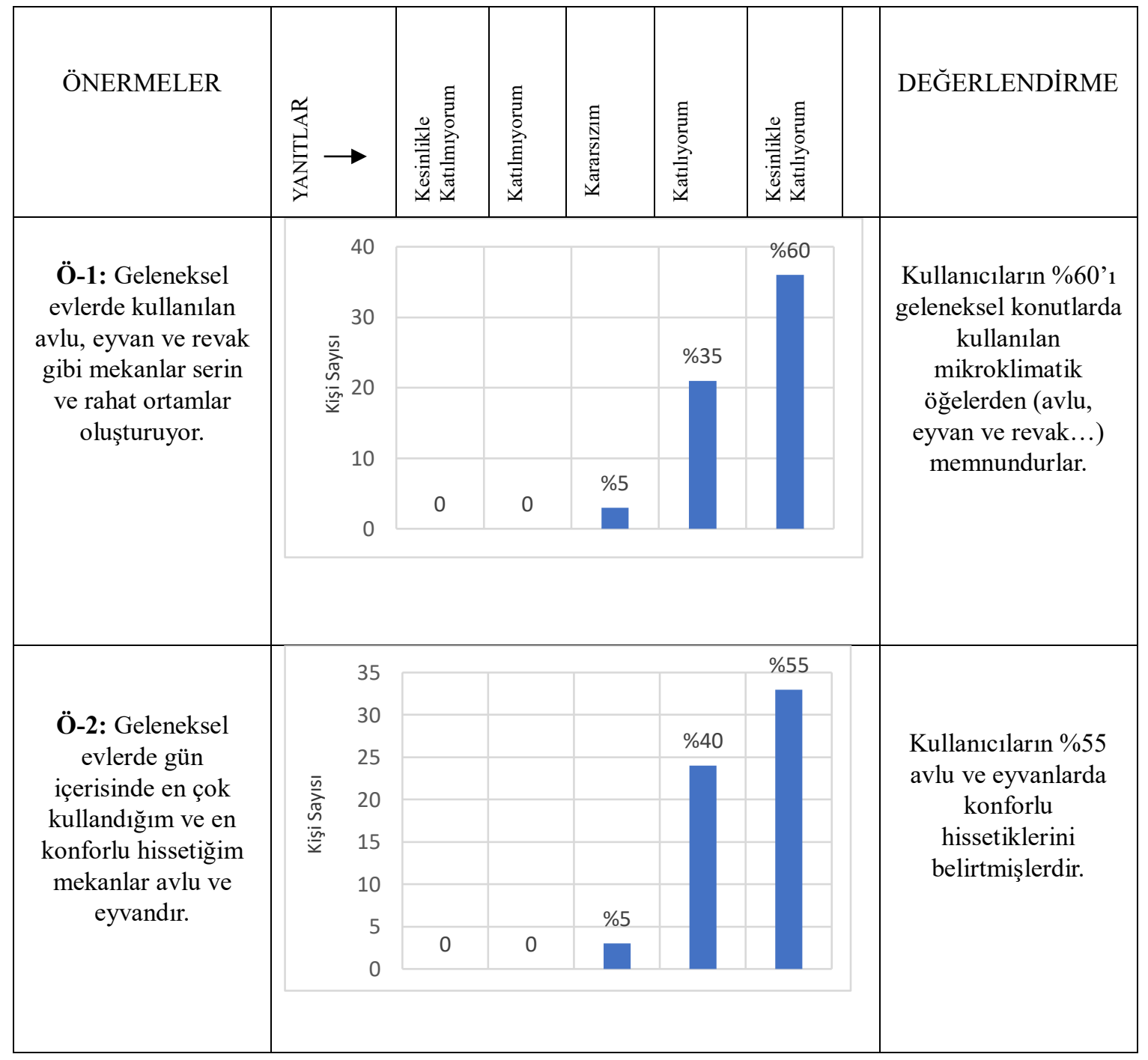




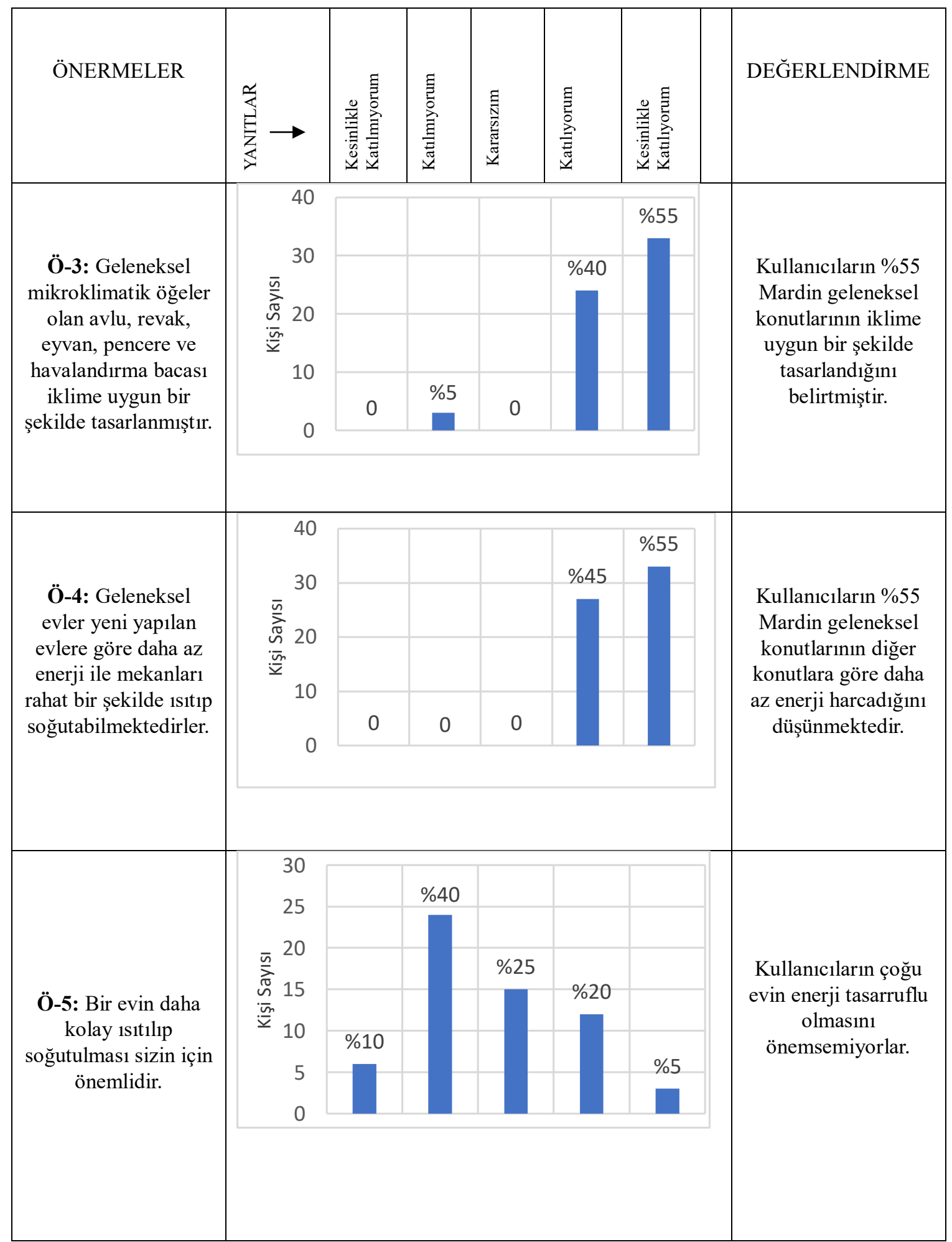




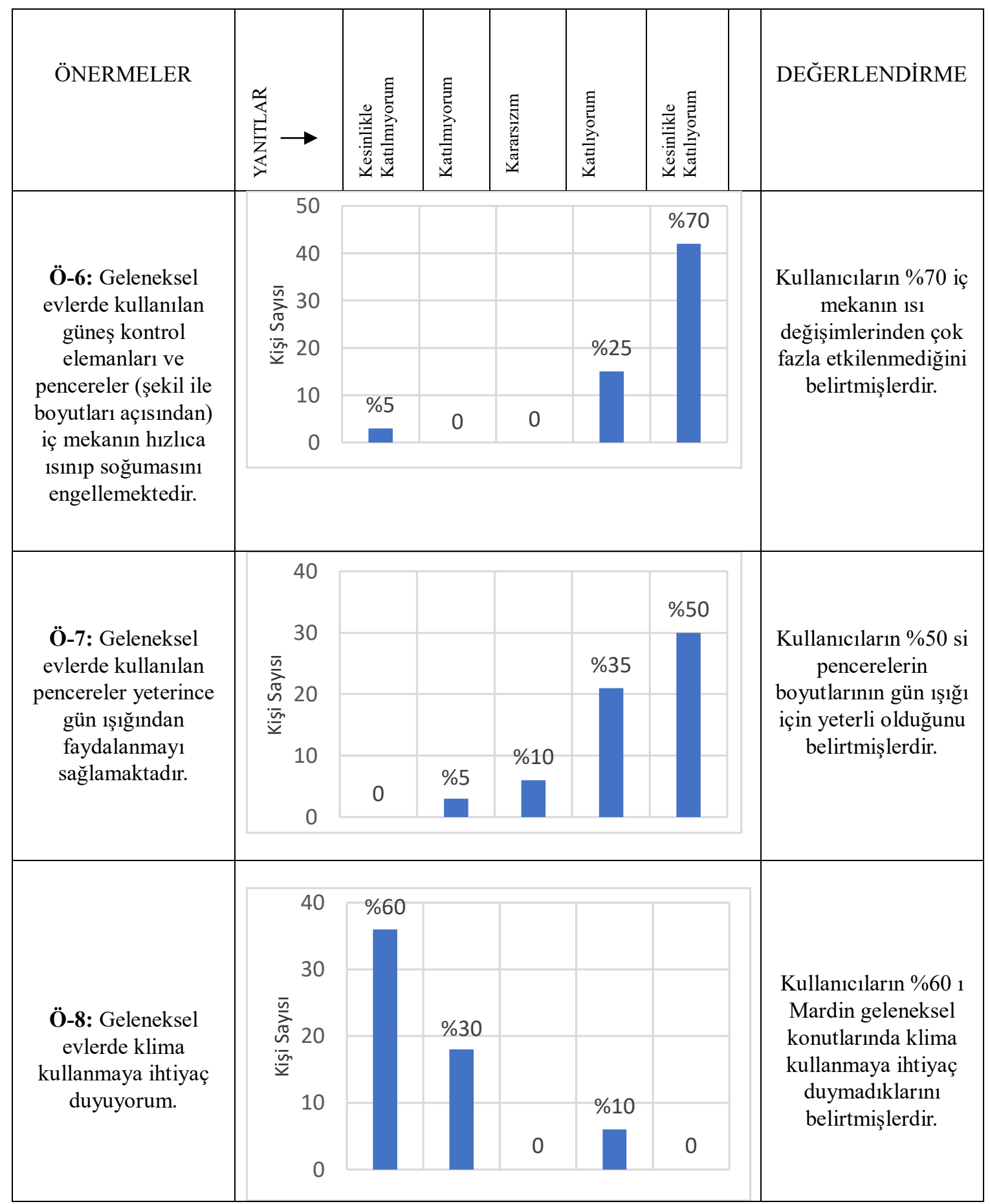




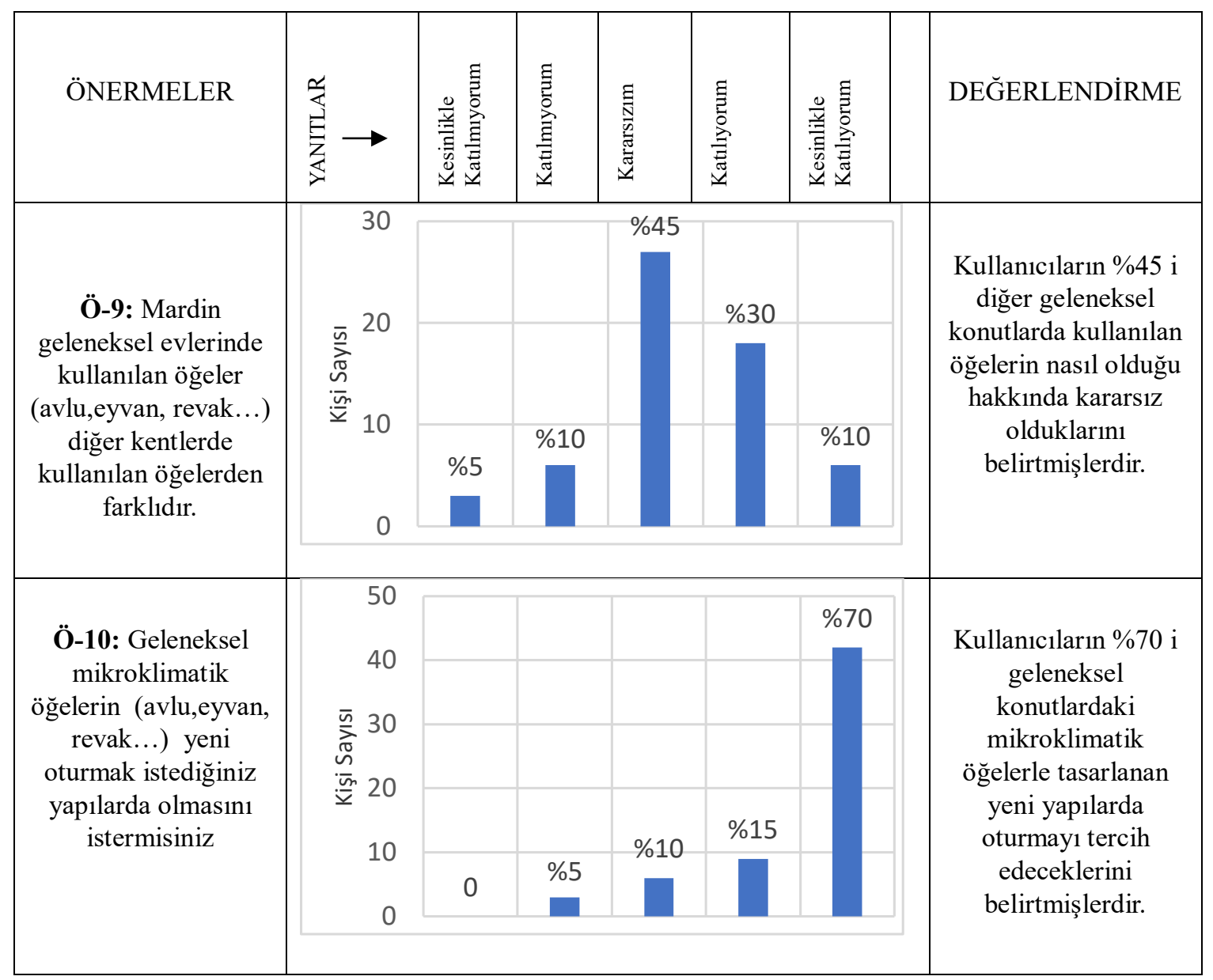

\section{SONUÇ VE ÖNERILER}

Mikroklimatik öğelerin enerji etkin kullanımdaki rolünün kullanıcı tarafından algısının belirlenmesi gözlem ve önermeler sonucundaki verilere göre değerlendirilmiştir.

Çalışma kapsamında mikroklimatik öğe olarak ele alınan avlu, eyvan, revak, pencere ve güneş kontrol elemanları için ayrı sonuçlar elde edilmiş ve yeni tasarımlar için öneriler oluşturulmuştur.

Geleneksel evlerde mikroklimatik öğe olan avlu bir veya iki katlı binalarda kullanılmıştır. Günümüzde arsa fiyatlarının artışı ve hızla artan nüfus beraberinde dikey mimarinin ağırlık kazanmasına ve bunun sonucu olarak yüksek katlı binaların miktarının artmasına sebep olmuştur. Yüksek katlı binalar mekanlar arasındaki hava akışını kesmektedir. Bu nedenle yüksek katlı binalarda avlu kullanımının ara katlarda boşluklar açılarak tasarlanması bir farkındalık olacaktır. Bu tasarım yaklaşımı aynı zamanda kullanıcılara ortak sosyal alan sunmanın yanında doğal olarak enerji üreten alan niteliğindedir. Yaz mevsimi için daha hızlı hava sirkülasyonu sağlayarak serin bir ortam oluşmaktadır (Şekil 4-5). 


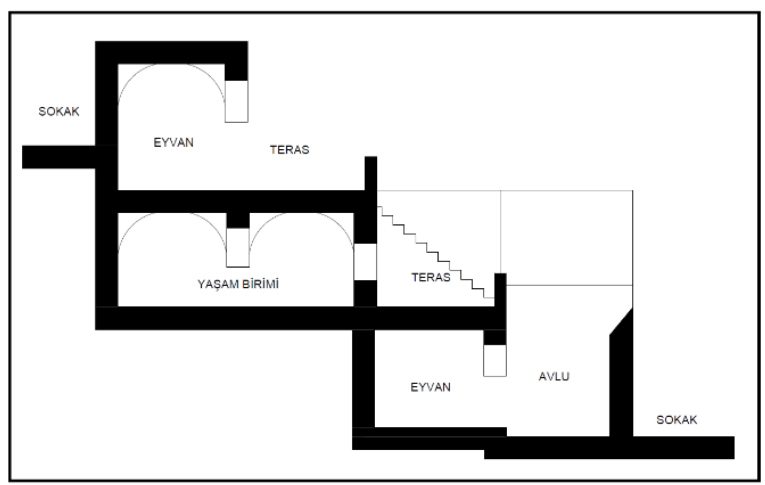

Şekil 4: Geleneksel evlerde avlu kesiti (Alioğlu, 2000)

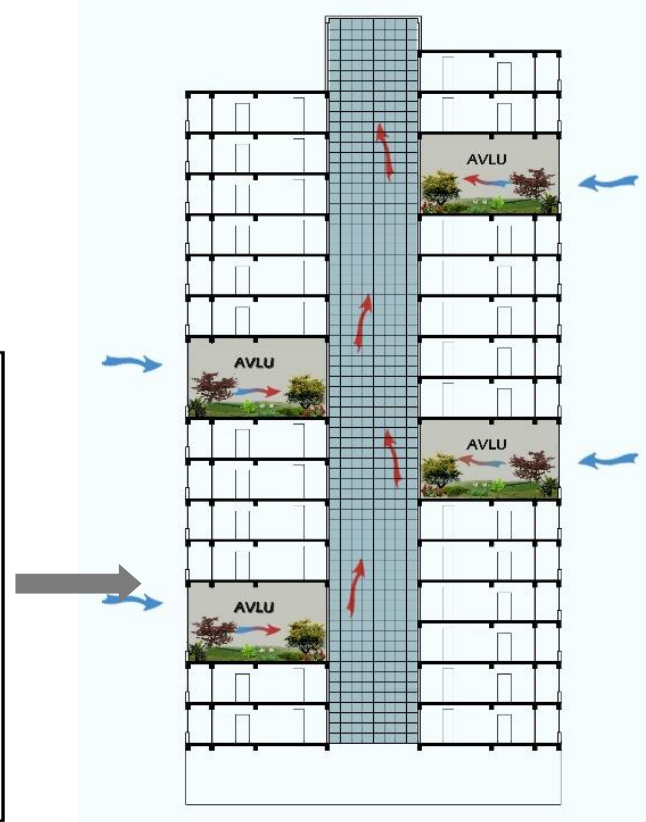

Şekil 5: Günümüz konutlarında avlu kesiti (Kübra Koçhan)

Mardin geleneksel evlerinde kullanılan eyvanlar doğu, batı ve en çokta güneye bakacak şekilde konumlandırılmıştır. Bu konumlandırma eyvanlarda öğleden sonraları için gölgeli ve serin alanalar oluşturmaktadır.

Apartman yapılarında eyvanların tasarım kriterleri göz önüne alınarak yapılara entegre edilmelidir. Dublex olarak tasarlanan yapılarda eyvanlar özellikle yön faktörleri göz önünde bulundurularak kullanılmalıdır (Şekil 6-7).

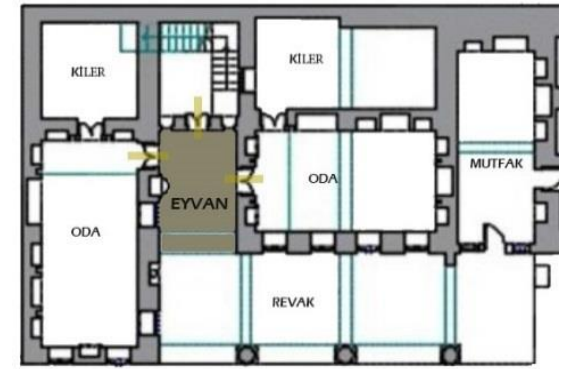

Şekil 6: Geleneksel evlerde eyvan planı (Bekleyen, ve ark. 2014)

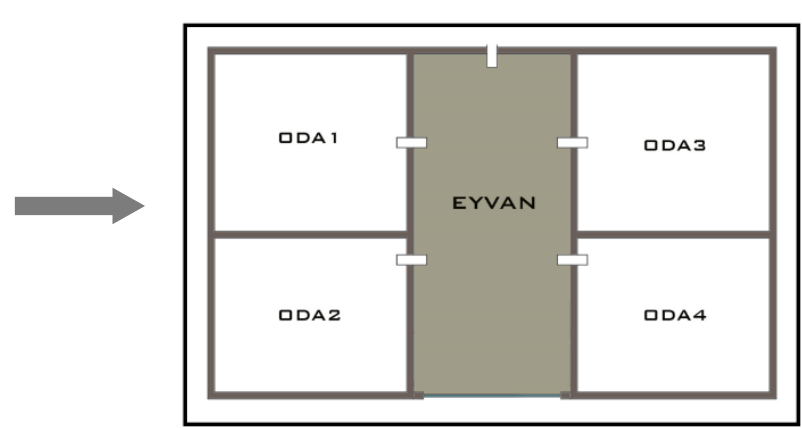

Şekil 7: Günümüz konutlarında eyvan planı (Kübra Koçhan ve Ayhan Bekleyen)

Günümüzde geleneksel evlerdeki revaklar önü camla kapatılarak kullanılmıştır. Bu kullanım yazın istenildiğinde camın tamamen açılmasını, kışın ise kapanmasını sağlamaktadır. 
Apartman gibi yapı tasarımlarında dairelerin ortak kullanım alanları revaklar şeklinde tasarlanıp hava sürkilasyonu ve gölgeleme sağlamış olacaktır (Şekil 8).

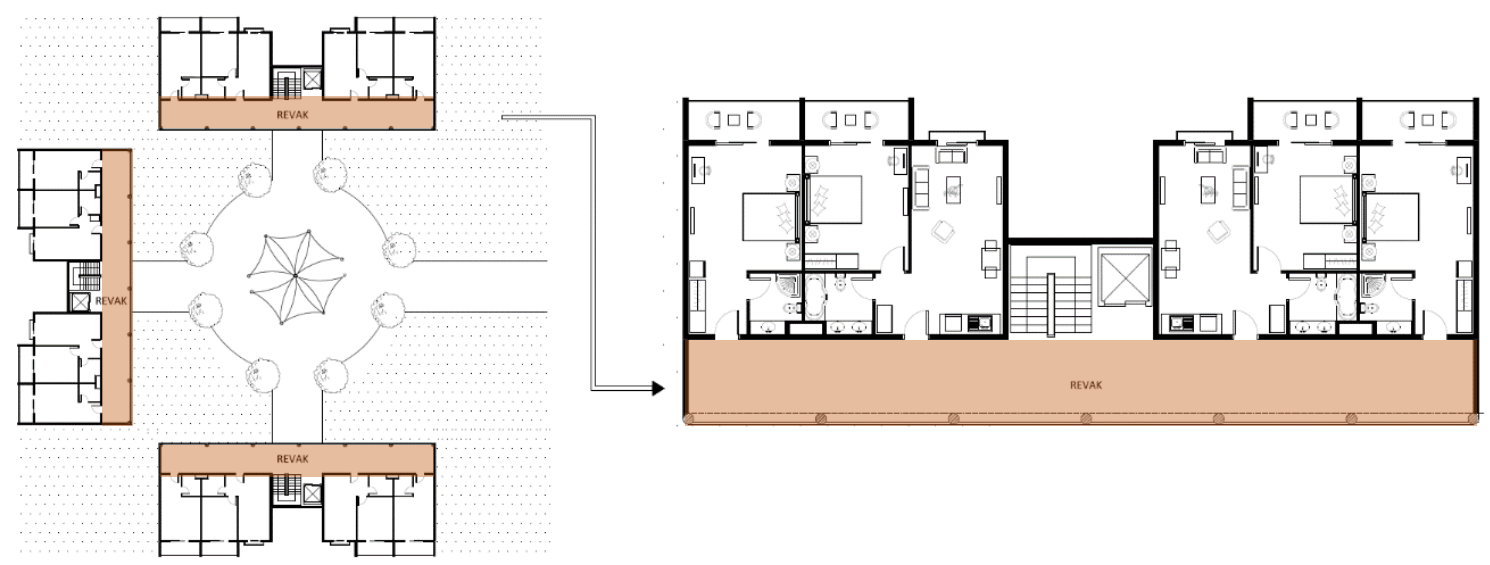

Şekil 8: Günümüzde revak kullanımı

Sıcak kuru iklimlerde yaz aylarında güneş ışınlarından kaçınmak oldukça önemlidir. Güneş ışınlarından kaçınmak için saçak kullanımı ve hareketli gölgeleme elemanlarını yapılarımızda kullanabiliriz.

Bina dışında güneş kontrol elemanları sayesinde güneşten korunma sağlanabilmektedir. İhtiyaç veya isteğe göre otomatik ya da manuel olarak tasarlanacak elemanlar bu amaçla kullanılabilecektir (Şekil 9).
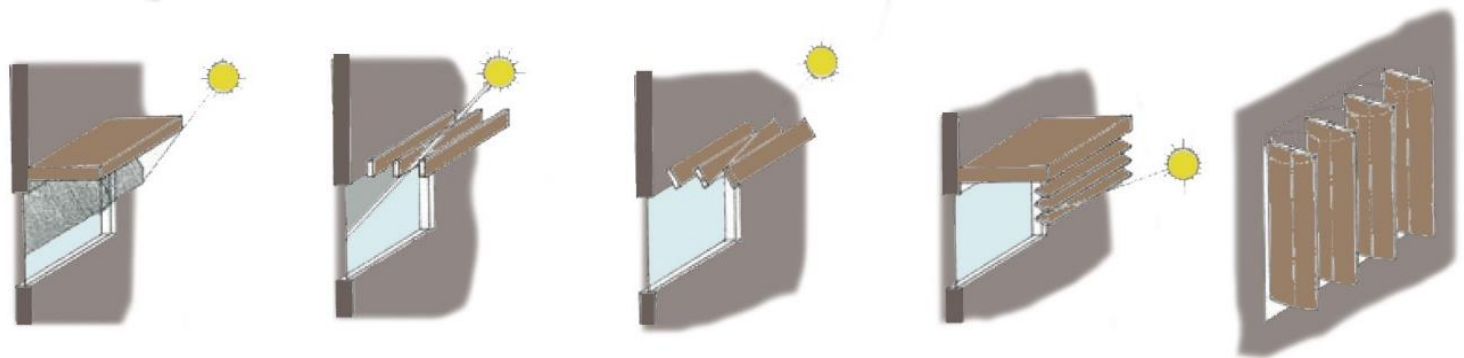

Şekil 9: Yapı dışından güneş kontrol elemanları önerisi (Koca, 2006)

Çalışmada kullanıcılar Mardin geleneksel konutlarında daha konforlu ve kullanışlı mekanların olduğunu öne sürmüşlerdir. Tasarımcıların bu mekanlardaki tasarım kriterlerini dikkate alarak yeni yapılacak olan yapılara bu kriterleri entegre ederek kullanmaları daha konforlu ve kullanışlı mekanların oluşmasını sağlayabilir.

\section{KAYNAKLAR}

Koca, Ö. (2006). Sıcak Kuru Ve Sıcak Nemli İklim Bölgelerinde Enerji Etkin Yerleşme Ve Bina Tasarım İlkelerinin Belirlenmesine Yönelik Yaklaşım. Yüksek Lisans Tezi, İ.T.Ü. Fen Bilimleri Enstitüsü, İstanbul, 1, 50, 70, 44, 81-83.

Sür, A. (1980). Lokalklima ve Mikroklima. [Online] Erişim: http://tucaum.ankara.edu.tr/wpcontent/uploads/sites/280/2015/08/cadcae9_3.pdf. (Erişimim Tarihi: 13.04.2019) 
Şimşek, N. (2013). Mardin Geleneksel Konutlarında Değişimin Mekân Dizimi Yöntemiyle İrdelenmesi. Yüksek Lisans Tezi, İ.T.Ü. Fen Bilimleri Enstitüsü, İstanbul, 53.

Manioğlu, G. (2008). [Online] Erişim: https://docplayer.biz.tr/21337624-Geleneksel-mimarideiklimle-uyumlu-binalar-mardin-de-bir-ogrenci-atolyesi.html. (Erişim Tarihi: 03.05.2019), 83,84 .

Özbek, H. (2004). Gelenekselden Türeyen Çağdaş Mardin Konut Yerleşimi. Yüksek Lisans Tezi, Y.T.Ü. Fen Bilimleri Enstitüsü, İstanbul, 42,46.

Salur, H. (2016). Avlulu Yapılarda Termal Konfor Analizi: Kayseri Köşk Medrese Örneği. Yüksek Lisans Tezi, E.Ü. Fen Bilimleri Enstitüsü, Kayseri, 38.

Alioğlu, E. F. (2000). Mardin şehir dokusu ve evler. Türkiye Ekonomik ve Toplumsal Tarih Vakfı Yayını, İstanbul, 57, 72, 77-85.

Karagülle, C. (2009). Yerel Verilerin Konut Tasarımı Sürecinde Değerlendirilmesi: Mardin Örneği. Doktora Tezi, İ.T.Ü. Fen Bilimleri Enstitüsü, İstanbul, 226.

Bekleyen, A., Dalkılıç, N., Özen, N. (2014). Geleneksel Mardin evinin Mekânsal ve Isısal Konfor Özellikleri. Türk Bilim Araştırma Vakfi, 38. 